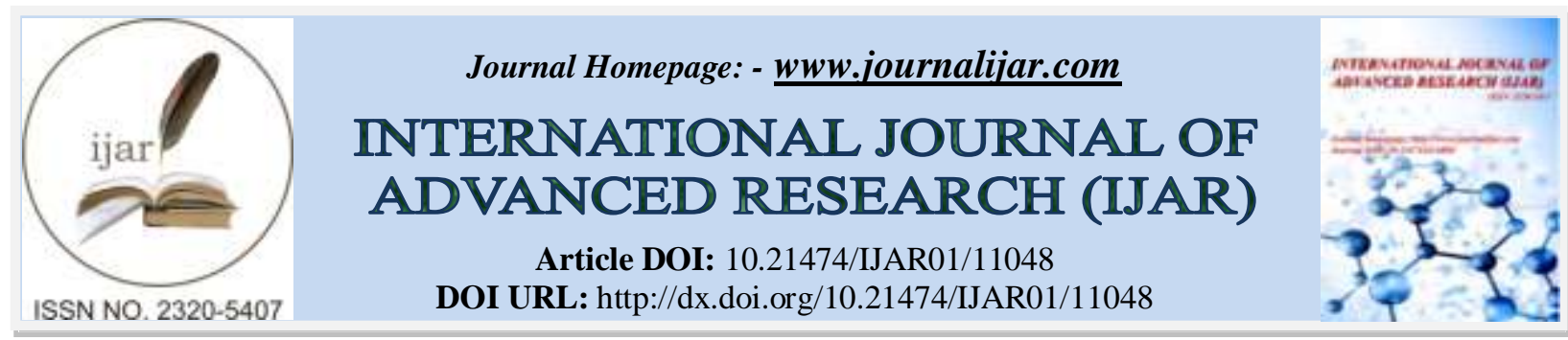

\title{
RESEARCH ARTICLE \\ STABILITY OF THE CONSTITUTION: FOUNDATIONS AND PROCEDURE FOR AMENDING THE BASIC LAW OF THE STATE
}

Mukhamedov Utkirbek Khazratkulovich

Doctor of Law, Professor.

\begin{abstract}
Manuscript Info
(1.........................

Manuscript History

Received: 25 March 2020

Final Accepted: 30 April 2020

Published: May 2020

Key words:-

Constitution, Fundamental Law,

Stability of the Constitution, Grounds for

Amending, Procedure for Amending the

Constitution, International Experience
\end{abstract}

\begin{abstract}
The article analyzes the theoretical foundations of the stability of the Constitution as the main law of the state, considers the basis and procedure for amending the Constitution, makes suggestions for improving this mechanism.
\end{abstract}

\section{Introduction:-}

In modern conditions of a rapidly changing world, facing new threats to stability and development of states, there is a need to amend the rules governing social relations, in particular, the constitutional norms of the country. In accordance with the Action Strategy for the five priority areas of the development of the Republic of Uzbekistan in 2017-2021, a radical improvement in the quality of legislative activity was determined, aimed at strengthening the influence of the laws adopted on the course of socio-political, socio-economic, judicial and legal reforms [1].

Of course, our Constitution did not remain unchanged, as it was necessary, until today, certain amendments were made to it. This approach is fully justified, because, as President of the Republic of Uzbekistan Sh.M. Mirziyoyev noted, "when it comes to the completeness, vitality and mechanisms of direct action of laws, ... we still have a lot to do in this direction" [2].

So, in accordance with article 15 of the Constitution of the Republic of Uzbekistan, the unconditional supremacy of the Constitution and laws of the Republic of Uzbekistan is recognized in the Republic of Uzbekistan [3]. The state, its bodies, officials, public associations, citizens act in accordance with the Constitution and laws.

Amending the Constitution is a change in the content of norms, rules and legal institutions by introducing amendments and additions to the current Constitution of the country.

The Constitution of the Republic of Uzbekistan is the Basic Law of our state and society. It reflects the issues of building a state, relations between people and the state, the powers of the President, the Oliy Majlis, the Cabinet of Ministers, and the Supreme Court of the Republic of Uzbekistan.

The constitution defines the main directions of our life. And therefore, other adopted laws, by-laws and any normative acts must comply with it. That is why the Constitution is called the Basic Law. 
The stability of the Constitution is an important legal feature, which guarantees constant, even, long-term regulation of the organization and exercise of state power in the country, ensures a balance and continuity of the development of legal relations in society. It ensures the continued operation of the Basic Law over a long period. At the same time, this does not mean that the Constitution is absolutely unchanged and that no changes are made to it.

With the change of time, society, and for other reasons, laws are being improved. In addition, the Constitution and laws express the will of the people. It is necessary to accept as a rule the introduction of certain amendments and additions to the Constitution, based on changes in the life of the state and society. When making amendments and additions to the Constitution, many questions are taken into account: what should be the state system, how should state bodies, political organizations and others work. All these aspects are reflected in the Constitution. When implementing its policy, the state, of course, relies on the Constitution. Each adopted law must comply with the Constitution, the norms enshrined in it.

It should be noted that in recent years, citizens have increased their observance of their rights and obligations, as specified in the Constitution. The President of the Republic of Uzbekistan pays special attention to this issue. A significant role in this direction is played by the creation of the People's Receptions of the President, the leaders of the visiting receptions of citizens and the improvement of the system of handling public appeals, the reform of the judicial system and its rapprochement with the people, the actual provision of freedom of speech to citizens, the creation of opportunities for free speech in the press and other factors. Of particular importance is the issue of respect for human rights in every adopted law, decrees and resolutions of the head of our state. For example, in the adopted Constitution of the Republic of Uzbekistan on December 8, 1992 at the eleventh session of the Supreme Council of the Republic of Uzbekistan of the twelfth convocation. During the validity of the Constitution of the Republic of Uzbekistan, various changes were made to it ten times, namely, amendments were made based on the results of a nationwide referendum held on January 27, 2002, and in accordance with the Law of the Republic of Uzbekistan dated April 23, 2003, amendments and additions were made to it chapters XVIII (Oliy Majlis of the Republic of Uzbekistan), XIX (President of the Republic of Uzbekistan), XX (Cabinet of Ministers), XXIII (Electoral system). The Law of the Republic of Uzbekistan dated April 11, 2007 amended Article 89 (President of the Republic of Uzbekistan), paragraph 15 of Article 93, part two of Article 102 of the Constitution of the Republic of Uzbekistan. The Law of the Republic of Uzbekistan dated December 25, 2008 amended the first part of Article 77 of the Constitution of the Republic of Uzbekistan (Oliy Majlis of the Republic of Uzbekistan). The Law of the Republic of Uzbekistan dated April 18, 2011 amended and supplemented Articles 78, 80 (Oliy Majlis of the Republic of Uzbekistan), 93, 96 President of the Republic of Uzbekistan), 98 (Cabinet of Ministers) of the Constitution of the Republic of Uzbekistan. The Law of the Republic of Uzbekistan dated December 12,2011 amended the second part of Article 90 of the Constitution. The law of the country on April 16, 2014 amended and supplemented articles 32, 78, 93, 98, 103 and 117 of the Constitution. The Law of the Republic of Uzbekistan dated April 6, 2017 amended and supplemented paragraph 4 of article 80, part seven of article 81, article 83, paragraphs 13 and 14 of part one of article 93, part one of article 107, part one and three of article 110, article 111 of the Constitution of the Republic Uzbekistan The Law of the Republic of Uzbekistan dated May 31, 2017 amended paragraphs 5 and 12 of Article 80, paragraph 13 of the first part of Article 93, Articles 108, 109 of the Constitution of the Republic of Uzbekistan. The Law of the Republic of Uzbekistan dated August 29, 2017 amended articles 99 and 102 of the Constitution of the Republic of Uzbekistan. The Law of the Republic of Uzbekistan dated October 15, 2018 amended the first part of Article 105 of the Constitution of the Republic of Uzbekistan.

For example, on August 24, 2019, the twenty-first plenary meeting of the Senate of the Oliy Majlis of the Republic of Uzbekistan continued to work in Tashkent, where the Senators began work by discussing the Law of the Republic of Uzbekistan "On Amendments and Additions to Some Legislative Acts of the Republic of Uzbekistan in Connection with the Implementation of New Formation Mechanisms and implementation of the budget of the Oliy Majlis of the Republic of Uzbekistan ", as well as changes to the Constitution of the Republic of Uzbekistan, constitutional laws, laws of the Republic of Uzbekistan were considered "On the referendum of the Republic of Uzbekistan", "On the State Emblem of the Republic of Uzbekistan", "On the State Anthem of the Republic of Uzbekistan" and others, in connection with the adoption of the Electoral Code of the Republic of Uzbekistan and in order to unify its norms in accordance with the legislation on elections.

An objective change in the tasks facing the state, the development and change of public relations, and the progress of society require improvement, and therefore, changes to the current Constitution and other legal acts. History shows that in none of the states that have chosen the democratic path of development, the constitution has not 
remained unchanged for a long time. Almost all constitutions, as necessary, albeit with different frequencies, introduced the corresponding changes and additions. The most extensive practice of reforming the Constitution is found in the United States of America, which is confirmed by the fact that the Constitution adopted in 1787 was amended 28 times [4, p.157-163]. Thanks to such transformations of the Constitution of the United States of America, it has existed for more than two centuries with minimal changes. As examples of the transformation of the Constitution of the United States of America, the amendment of such essential provisions of the Constitution as the rights of the black and white population (segregation), the expansion of the powers of public authorities, some other provisions.

It should be noted that the procedures used to amend the Constitution of the Republic of Uzbekistan are very diverse. When changing various provisions of the Constitution of the Republic of Uzbekistan, practically all methods are used to consider and approve changes by the legislative body of state power by an absolute majority of votes, as well as approve changes by the legislative body of state power using the simple and complex double vote procedure. Such an abundance of procedures indicates a balanced approach to the issues of changing the Constitution of the Republic of Uzbekistan, in which the complexity of one way or another way of changing the Constitution of the Republic of Uzbekistan is based on the social significance of public relations regulated by relevant provisions.

The Constitution is the main law of the state, regulating the most significant social relations, the core of the legal system of the state, an integral symbol of the rule of law, the most important institution of democracy. In this regard, one of its main properties is its stability, resistance to changes, which is ensured by the peculiarity of the mechanisms for changing the basic law.

Due to the fact that in recent times there are fewer and fewer constitutions, all the provisions of which are changing in the order in which ordinary laws are adopted and changed, the division of constitutions into rigid, flexible and mixed evolves and takes on a new meaning. More relevant is the consideration of individual constitutional provisions in accordance with the order in which they are amended.

In accordance with this approach, all constitutional provisions can be divided into three main groups:

1. constitutional provisions that change in a more complex manner than the procedure provided for the adoption and amendment of ordinary laws;

2. constitutional provisions that change in an order identical to the procedure for adoption and amendment of ordinary laws or by-laws and regulations;

3. constitutional provisions that are not subject to change under any circumstances.

The tougher the constitution, the more provisions therein referring to the third group of the proposed classification, the greater the likelihood of overcoming its rigidity through its complete abolition and adoption of a new fundamental law. In this regard, it seems important to choose a method of changing the constitution that would serve two purposes at the same time: a) maintaining the stability of the fundamental law, b) the ability to quickly adapt the fundamental law to public relations regulated by it.

Consideration of ways to change constitutions in foreign countries allowed us to identify the following basic procedures used when changing basic laws:

1. Approval of amendments to the constitution by the legislative body of state power. This group, in turn, is divided into four subgroups: a) approval of changes by an absolute majority of members of the legislative body of state power; b) approval of changes by a qualified majority of members of the legislative body of state power; c) approval of changes by the legislative body of state power using the "simple double vote" procedure;

2. Approval of amendments to the constitution by popular vote (referendum);

3. Approval of amendments to the constitution by the constituent authority (constituent body);

4. Approval of changes to the constitution by legislative bodies of state power;

5. The participation of the Head of State in changing the constitution.

In terms of the form of amending the text of the constitution, all the basic laws can be divided into two main groups:

1. Constitutions, amendments to which are made directly to the text of the fundamental law, thereby changing the wording of the originally adopted constitution; 
2. Constitutions, the original text of which remains unchanged, and the corresponding amendments exist in the form of independent legal acts.

An analysis of the practice of converting constitutions without changing the text of the relevant constitutional provisions suggests that the transformation of constitutions can be considered as one of the ways to change constitutions. Such ways of transforming constitutions include:

1. The official interpretation of constitutional norms;

2. The transformation of constitutional norms under the influence of judicial, administrative and parliamentary practice;

The basis for any such method of converting constitutions is the interpretation of the relevant constitutional provisions; constitutional reform can be used as a way to amend constitutions mainly in countries belonging to the Anglo-Saxon system of law, in which judicial precedent is one of the main sources of law.

\section{Bibliography:-}

1. Decree of the President of the Republic of Uzbekistan "On the Strategy for the Further Development of the Republic of Uzbekistan" dated February 7, 2017 No. UP-4947 // http://www.prezident.uz

2. Mirziyoyev Sh.M. Ensuring the rule of law and human interests is a guarantee of the development of the country and the well-being of the people // Report of the elected President of the Republic of Uzbekistan Shavkat Mirziyoyev at the solemn meeting dedicated to the 24th anniversary of the adoption of the Constitution of the Republic of Uzbekistan on December 9, 2016 // http: //www.prezident. uz

3. Constitution of the Republic of Uzbekistan in the Republic of Uzbekistan // http://www.prezident.uz

4. The United States Constitution // United States House of Representatives. - Electronic text data. - Mode of access: http://www.house.gov/house /Constitution/Constitution.html. 